\title{
BLOCKCHAIN TECHNOLOGY AND THE POSSIBILITIES OF ITS USE
}

\author{
V.V.Zakharov', metkol@yandex.ru, \\ V.L.Rybak', rybak1323@mail.ru \\ ${ }^{1}$ South Ural State University, Chelyabinsk, Russian Federation, \\ ${ }^{2}$ Financial University under the Government of the Russian Federation, \\ Moscow, Russian Federation
}

Introduction. With the development of digital technology, most familiar processes are changing. Without information technology, it is already impossible to imagine either medicine or the field of education. Big data and artificial intelligence come to almost every area of society, everything around is becoming "smart". According to the forecasts of the participants of the St. Petersburg International Economic Forum, held in 2019, the global market for products using artificial intelligence and advanced information technologies can grow by almost 17 times by 2024. A national strategy for the development of technologies in the field of artificial intelligence and information technologies has been prepared in the Russian Federation, and a detailed action plan has been integrated into the national program "Digital Economy". Digitalization today covers almost all aspects of the interaction of the citizen and business with authorities. Digitalization of business processes takes place, technologies are introduced into the activities of industrial enterprises, in the organization of public services and financial institutions.

Aim. Consider the technology of blockchain, its origin, advantages and disadvantages, as well as the possibilities and prospects of using this technology.

Materials and methods. As part of the materials and methods, one should point to an analysis of the theoretical foundations of the blockchain technology, the practical results of its implementation and use in various fields of activity: from public life to business. Since it is blockchain technology that occupies a special place among the promising information technologies and is increasingly used in business, as well as government, and will undoubtedly affect the familiar picture of the world, how the Internet has changed the world of information exchange in its time.

Results. The article makes an attempt to assess the origin, current state, the possibilities of using blockchain technology, as well as its impact on traditional business processes and socioeconomic transformation as a result of the digitalization process.

Conclusion. It is believed that blockchain technology can be a real breakthrough in the field of finance, secure databases and the reliability of certain facts. For the largest foreign and domestic companies, this is not just a concept from an approximate future, but now it is part of the business, and the future life of society as a whole depends on how well it is to use and manage blockchain technology.

Keywords: blockchain technology, digitalization, digital economy.

\section{Introduction}

In simple terms, blockchain is a database that is stored and updated simultaneously on different devices. Database management is autonomous and decentralized. The database stores and confirms the accuracy of the information and the safety of this data is provided by cryptographic algorithms. Information with this architecture is stored reliably, since many copies of the same data set are simultaneously stored on computers of an unlimited number of users of the entire system. Depending on the order of access to information, system management, participant's capabilities, a private blockchain and a public blockchain are distinguished. And each type of system is applicable to individual tasks of the project and to different goals [1-5].

\section{The origin of blockchain technology}

There are several versions of the origin of blockchain. The most common version is associated with the development in 2008 by Satoshi Nakamoto of the protocol of the famous Bitcoin cryptocurrency and the alternative infrastructure of the Bitcoin system of the same name. This system is based on the blockchain and quickly entered the business cycle. The second version is historically perhaps more fair. 


\section{Краткие сообщения}

The technology of software processing distributed databases has been known since the 70s of the last century to programmers and mathematicians who took a special course in "Structures and Algorithms for Data Processing" at higher educational institutions. It's just that this cryptographic technology, based on the well-known principles of distributed interaction, was not claimed by the business and the business community until a certain point, since there were other more understandable and affordable mechanisms for doing business. The third version of the origin of blockchain technology has a "spy subtext". Cryptographic data processing algorithms that protect this data from modification and hacking have long been developed and actively implemented in security agencies for military and intelligence purposes [6-10].

\section{Use of blockchain technology}

It is worth noting that blockchain is not only cryptocurrency and not only ISEO - international search engine optimization. Blockchain is also a system for registering rights and assets, for example, registration of copyrights, property rights, certification of transactions, etc. Blockchain technology is used in a broad sense to ensure the safety of the storage, use, retrieval and fixing of any kind of information. The bright areas of its application are the following [11-21]:

- transfers of funds and units of virtual currency;

- automatic execution of smart contracts [22, 23];

- confirmation of the origin and identification of complex, special or rare things (objects of art, jewelry);

- maintaining a register of assets, including ISEO, a register of rights, facts or actions;

- secure and anonymous voting;

- conducting trade calculations and logistics;

- improvement of the regime of financial transactions and reduce transaction costs.

In fact, with a competent approach and reliable observance of the unshakable principles of information reliability and data safety, there is practically no limit to the application of blockchain technology. Blockchain can also be actively used in financial markets, in particular when making cross-border interbank payments, for example, as part of the SWIFT system or its analogues. Blockchain technology is also the basis for such actively developing fields of activity around the world as:

- LegalTech - a business sector that provides information technology services for professional legal activities and the provision of legal services to consumers using IT;

- FinTech - a business sector consisting of companies that use technology and innovation to compete with traditional financial institutions represented by banks and intermediaries in the financial services market.

In addition, blockchain as a technology can be the basis for many financial, economic, social and legal processes.

\section{Advantages and disadvantages of blockchain technology}

The disadvantages of this technology are mainly technical and legal. For example, there may be doubts about the security of such technology, since the data registry does not have a single control center and can theoretically be hacked. In addition, since the transaction database is not linked to any specific territory or state, the rules for making transactions in different States may cause contradictions and legal conflicts [22]. There are also still open questions about the storage and protection of personal data of participants and users of systems based on blockchain technology, as well as questions about canceling and correcting erroneous or false transactions. At the same time, there is an engineering complexity of modern blockchain solution's architectures [24-26].

Speaking about the advantages of this technology, it should be noted, first of all, the functionality: blockchain is a flexible, open technology with potentially wide opportunities, which allows you to automatically conclude many transactions, register facts, which allows you to reduce the time, costs, and operational risks [27-30].

\section{Conclusion}

It is obvious that blockchain technology, as well as global ideas of decentralization, are becoming more and more popular in many areas of public life. Many companies, both in the manufacturing, finan- 
cial and social sectors, are working on implementing potentially promising technology for the development of their business. It is worth noting that the capabilities of this technology are already used in completely different spheres of life: from intellectual property rights to electronic medical records, as well as real estate turnover, and can qualitatively change our daily existence, so it is necessary to be prepared for further development and management of such technologies.

\section{References}

1. Kosba A. Hawk: The Blockchain Model of Cryptography and Privacy-Preserving Smart Contracts. 2016 IEEE symposium on security and privacy (SP), 2016, 839-858 pp.

2. Farmer J.A. The Spector of Crypto-anarchy: Regulating Anonymity-Protecting Peer-To-Peer Networks. L. Rev, 2003, vol. 72, pp. 725-725.

3. Zyskind G., Nathan O., Pentland A. Enigma: Decentralized Computation Platform with Guaranteed Privacy. arXiv preprint arXiv, 2015, 1506.03471.

4. Wood G. Ethereum: A Secure Decentralised Generalised Transaction Ledger. Ethereum project yellow paper, 2014, no. 151, 1-32 pp.

5. Dannen C. Introducing Ethereum and Solidity. Berkeley, Apress, 2017. 206 p.

6. Van Saberhagen N. CryptoNote v 2.0, 2013 [CryptoNote v 2.0, 2013]. Fvailiable at: https://cryptonote.org/whitepaper.pdf (accessed 02.03.2020)

7. Sun S.F. RingCT 2.0: a Compact Aaccumulator-Based (Linkable Ring Signature) Protocol for Blockchain Cryptocurrency Monero. European Symposium on Research in Computer Security, 2017, pp. 456-474.

8. Noether S. Ring Signature Confidential Transactions for Monero. IACR Cryptology ePrint Archive, 2015. $1098 \mathrm{p}$.

9. Miller A. An Empirical Analysis of Linkability in the Monero Blockchain. arXiv preprint, 2017, no. 1704.

10. Sasson E. B. Zerocash: Decentralized Anonymous Payments from Bitcoin. 2014 IEEE Symposium on Security and Privacy (SP), 2014, pp. 459-474.

11. Miers I. Zerocoin: Anonymous Distributed E-Cash from Bitcoin. 2013 IEEE Symposium on Security and Privacy (SP), 2013, pp. 397-411.

12. Hopwood D. Zcash Protocol Specification. Vol. 1.10. Zerocoin Electric Coin Company. Technical report, 2016.

13. Nakamoto S. Bitcoin: A Peer-to-Peer Electronic Cash System, 2008.

14. Eyal I., Sirer E.G. Majority is not Enough: Bitcoin Mining is Vulnerable. Communications of the ACM, 2018, vol. 61, no. 7, pp. 95-102.

15. Reid F., Harrigan M. An Analysis of Anonymity in the Bitcoin System. Security and Privacy in Social Networks, 2013, pp. 197-223.

16. Buterin V. Next-Generation Smart Contract and Decentralized Application Platform [A Smartkontrakt sleduyushchego pokoleniya i detsentralizovannaya prikladnaya platforma], Ethereum White Paper, 2014, pp. 1-36.

17. Clack C.D., Bakshi V.A., Braine L. Smart Contract Templates: Foundations, Design Landscape and Research Directions, arXiv: 1608.00771v3, 2016, pp. 1-15.

18. Bartoletti M., Pompianu L. An Empirical Analysis of Smart Contracts: Platforms, Applications and Design Patterns. International Conference on Financial Cryptography and Data Security, 2017, pp. 494-509.

19. Bartoletti M., Pompianu L. An Empirical Analysis of Smart Contracts: Platforms, Applications and Design Patterns. International Conference on Financial Cryptography and Data Security, 2017, pp. 494-509.

20. Duffield E., Hagan K. Darkcoin: PeertoPeer CryptoCurrency with Anonymous Blockchain Transactions and an Improved ProofofWork System [Darkcoin: kriptovalyuta PeertoPeer s anonimnymi tranzaktsiyami blokcheyna i uluchshennoy sistemoy ProofofWork], 2014.

21. Duffield E., Diaz D. Dash: A PrivacyCentric CryptoCurrency, 2015.

22. Raskin M. The Law and Legality of Smart Contracts [Zakon i zakonnost' smart-kontraktov], 2016. 


\title{
Краткие сообщения
}

23. Yuan R. ShadowEth: Private Smart Contract on Public Blockchain. Journal of Computer Science and Technology, 2018, vol. 33, no. 3, pp. 542-556.

24. Ruj S. BlockStore: A Secure Decentralized Storage Framework on Blockchain. 2018 IEEE 32nd International Conference on Advanced Information Networking and Applications (AINA), 2018, pp. 1096-1103.

25. Sánchez D.C. Raziel: Private and Verifiable Smart Contracts on Blockchains [Raziel': chastnyye i proveryayemyye smart-kontrakty na blokcheynakh], 2018.

26. Cheng R. Ekiden: A Platform for Confidentiality-Preserving, Trustworthy, and Performant Smart Contract Execution [Platforma dlya sokhraneniya konfidentsial'nosti, nadezhnosti i effektivnosti ispolneniya smart-kontraktov], 2018.

27. Swan M. Blockchain: Blueprint for a new economy [Blokcheyn: proyekt novoy ekonomiki], 2015.

28. Zyskind G. Decentralizing Privacy: Using Blockchain to Protect Personal Data. Security and Privacy Workshops (SPW), 2015, pp. 180-184.

29. Cachin C. Architecture of the Hyperledger Blockchain Fabric. Workshop on Distributed Cryptocurrencies and Consensus Ledgers, 2016, vol. 310.

30. Guo Y., Liang C. Blockchain Application and Outlook in the Banking Industry. Financial Innovation, 2016, vol. 2, no. 1, pp. 24-24.

Received 14 June 2020

Удк 004.9

DOI: $10.14529 /$ ctcr200315

\section{TЕХНОЛОГИЯ BLOCKCHAIN И ВОЗМОЖНОСТИ ЕЕ ИСПОЛЬЗОВАНИЯ}

\author{
В.В. Захаров ${ }^{1}$, В.Л. Рыбак ${ }^{2}$ \\ ${ }^{1}$ Южно-Уральский государственный университет, г. Челябинск, Россия, \\ ${ }^{2}$ Финансовый университет при Правительстве РФ, г. Москва, Россия
}

Введение. С развитием цифровых технологий меняется большинство привычных процессов. Без информационных технологий уже невозможно представить ни медицину, ни сферу образования. Большие данные и искусственный интеллект приходят практически в каждую сферу жизни общества, все вокруг становится «умным». По прогнозам участников Петербургского международного экономического форума, проходившего в 2019 году, мировой рынок продуктов с использованием искусственного интеллекта и перспективных информационных технологий к 2024 году может вырасти почти в 17 раз. В Российской Федерации подготовлена национальная стратегия развития технологий в области искусственного интеллекта и информационных технологий, а детальный план действий интегрирован в национальную программу «Цифровая экономика». Цифровизация сегодня охватывает почти все стороны взаимодействия гражданина и бизнеса с органами власти. Происходит цифровизация бизнеспроцессов, технологии внедряются в деятельность промышленных предприятий, в организацию государственных услуг и финансовых учреждений.

Цель исследования. Рассмотреть технологию blockchain, eе происхождение, достоинства и недостатки, а также возможности и перспективы применения данной технологии.

Материалы и методы. В составе материалов и методов следует указать на анализ теоретических основ технологии blockchain, практических результатов ее внедрения и использования в различных сферах деятельности - от общественной жизни до бизнеса, так как именно технология blockchain занимает особое место в ряду перспективных информационных технологий и находит все большее применение в сфере бизнеса, а также государственного управления и, несомненно, повлияет на привычную картину мира, как в свое время Интернет изменил мир обмена информацией. 
Результаты. В статье делается попытка оценить происхождение, текущее состояние, возможности использования технологии blockchain, а также ее влияние на традиционные бизнеспроцессы и социально-экономическую трансформацию в результате процесса цифровизации.

Заключение. Считается, что технология blockchain способна стать настоящим прорывом в области финансов, защищенных баз данных и достоверности тех или иных фактов. Для крупнейших зарубежных и отечественных компаний это не просто понятие из приближенного будущего, а уже сейчас часть бизнеса, и от того, насколько грамотно подходить к применению и управлению технологией blockchain, зависит и будущая жизнь общества в целом.

Ключевые слова: технология blockchain, ц̧ифровизаџия, цүифровая экономика.

Захаров Вадим Владимирович, инженер кафедры информационно-аналитического обеспечения управления в социальных и экономических системах, Южно-Уральский государственный университет, г. Челябинск; metkol@yandex.ru.

Рыбак Вадим Львович, студент 2-го курса магистратуры, Финансовый университет при Правительстве РФ, г. Москва; rybak1323@ mail.ru.

Поступила в редакцию 14 июня 2020 г.

\section{ОБРАЗЕЦ ЦИТИРОВАНИЯ}

Zakharov, V.V. Blockchain Technology and the Possibilities of Its Use / V.V. Zakharov, V.L. Rybak // Вестник ЮУрГУ. Серия «Компьютерные технологии, управление, радиоэлектроника». - 2020. - Т. 20, № 3. C. 135-139. DOI: $10.14529 /$ ctcr200315

\section{FOR CITATION}

Zakharov V.V., Rybak V.L. Blockchain Technology and the Possibilities of Its Use. Bulletin of the South Ural State University. Ser. Computer Technologies, Automatic Control, Radio Electronics, 2020, vol. 20, no. 3, pp. 135139. DOI: $10.14529 /$ ctcr200315 